\title{
МЕЖКУЛЬТУРНАЯ КОММУНИКАЦИЯ В МЕТОДИКЕ ПРЕПОДАВАНИЯ ИНОСТРАННОГО ЯЗЫКА
}

\section{INTERCULTURAL COMMUNICATION IN THE METHODOLOGY OF TEACHING A FOREIGN LANGUAGE}

\section{Konkol}

Summary: The article explores an intercultural approach to teaching a foreign language. The analysis is focused on intercultural communication as a means of developing intercultural competence based on the dialogue of cultures. The research studies intercultural competence as the main component of interculturally-oriented learning.

Keywords: intercultural competence, intercultural communication, cultural dialogue, interculturally-oriented learning.
Конколь Марина Михайловна

К.п.н., старший преподаватель, МГИМО МИД России konkolio@mail.ru

Аннотация: Исследование посвящено проблеме межкультурного подхода в обучении иностранному языку.

В фокусе внимания - межкультурная коммуникация, развивающая у учащегося-медиатора коммуникации культур качества для осуществления межкультурного общения на основе диалога: межкультурную компетенцию, культурно-обусловленное поведение, использование иностранного языка как систему культурных ценностей.

В работе анализируется межкультурная компетенция как основной компонент межкультурно-ориентированного обучения, одной из основных задачей которого является формирование личности, готовой к межкультурному общению, в котором на передний план выходит межкультурная компетенция, помогающая эффективно вести диалог культур, при котором учитываются особенности собственной и иных культур. В современной реальности межкультурный компонент предполагает развитие способности вести диалог, формировать межкультурную толерантность по отношению к иным, отличным от собственных взглядам, обычаям, традициям, иному опыту, иным нормам и культурным представлениям.

Ключевые слова: межкультурная компетенция, межкультурная коммуникация, диалог культур, межкультурно-ориентированное обучение.
$\mathrm{B}$ настоящее время на смену коммуникативному приходит межкультурный подход в обучении иностранному языку, межкультурная парадигма образования. Это сочетание с компетентностным подходом привело к возникновению понятия «межкультурная компетенция».

Коммуникативный подход, господствующий с 1980-х гг., предполагает изучение иностранного языка благодаря общению и ориентировано на достижение иноязычной речевой компетенции, которая моделируется по образцу репрезентации носителя языка, при этом не тождественна. Исследователи выделяют в структуре такие компоненты, как: лингвистическую (языковую), прагматическую, стратегическую, дискурсивную, социокультурную субкомпетенции (И.Л. Бим, В.В. Сафонова, Г.В. Елизарова, Р.П. Мильруд), (Анненкова).

Необходимо разграничить обучение иностранному языку как второму и обучение языку как иностранному, протекающее в условиях изоляции от культурной среды изучаемого языка. В российской системе среднего образования мы имеем дело исключительно со вторым типом.

Можно согласиться с Г.В. Елизаровой о не тожде- ственности коммуникативной компетенции носителя языка: «Природа, компонентный состав и структура иноязычной коммуникативной компетенции отличается от структуры коммуникативной компетенции в родном языке». [7, 92] Данная идея носит принципиальный характер, так как идеалом обучения является не носитель языка, а языковая личность в роли медиатора коммуникации культур.

Традиционный коммуникативный подход в преподавании иностранных языков не всегда учитывает специфику речевой деятельности как культурно-обусловленного поведения и языка как отражение системы культурных ценностей. Большое значение приобретает вопрос совершенствования иноязычной подготовки, повышения уровня межкультурной образованности обучающихся.

Актуальной становится задача формирования данной компетенции не только у взрослых, студентов языковых и неязыковых вузов, но и школьников. Необходимость формирования межкультурной компетенции у всех обучающихся обосновывается прогрессирующим увеличением их непосредственных и опосредованных (через Интернет) контактов с представителями иных культур. Необходимо отметить, что основными пробле- 
мами недопонимания между представителями разных культур являются не ошибки лингвистического плана, а отсутствие представления о правилах и нормах менталитета людей других стран, стратегические ошибки в вербальном общении. [6, 137].

Возникает ситуация, когда коммуниканты, пользуясь одним и тем же языком, неодинаково воспринимают передаваемые сообщения из-за разницы в социокультурном опыте.

Межкультурное ориентированное обучение иностранному языку не должно имитировать обучение иностранному языку как второму, оно требует принципиально новой модели преподавания, учитывающей зарубежные методики обучения иностранному языку как иностранному, адаптированные к условиям современной российской действительности.

Анализ научно-методической литературы (Е.И. Пасов, А.А. Миролюбов, Н.Д. Гальскова) показывает смещение целей обучения иностранного с языковой нормы как системы (начало XX в.) на язык как средство общения (1960-е гг.), и язык как средство познания иных культур (с начала 1980-х гг.).

Одновременно начинает развиваться личностноориентированное обучение (Л.С. Выготский А.А. Леонтьев, И.А. Зимняя, И.Л. Бим). Личность обучаемого выходит на первый план, учитываются его интересы, склонности, основное внимание уделяется обеспечению условий для самореализации и саморазвития личности. Учащийся становится активным субъектом познавательной деятельности. Идея личностно-ориентированного обучения продолжила свое развитие и получила межкультурную ориентацию. В наше время все чаще в методической литературе упоминается задача формирования личности, готовой к межкультурному общению. Целью иноязычного образования становится вторичная языковая личность, межкультурный коммуникант (медиатор культур) [7], культурно-ориентированная личность (В.П. Фурманова), межкультурно-ориентированная личность. Иначе говоря, современное лингвистическое образование ориентировано как личностно, так и межкультурно. Язык стал средством проникновения в мировую культуру, познания мировых ценностей, осознания собственной культурной принадлежности. В связи со сменой коммуникативной образовательной парадигмы на межкультурную, на передний план выходит категория «межкультурной компетенции» как цели обучения иностранным языкам $[1,299]$. Речь идет именно о межкультурной коммуникации, о диалоге культур, при котором необходим учет культурно-исторических особенностей собственной и иных культур, а не об общении с представителями иных лингвосоциумов. Таким образом, в средних школах уделяется внимание качествам личности, необходимым для успешного межкультурного общения.

Усиление глобализационных и интеграционных процессов, охватывающих сферы экономики, культуры, науки и образования в нашей стране, ведет к увеличению количества межкультурных контактов, что, в свою очередь, обусловливает важность владения иностранным языком, необходимость межкультурной подготовки коммуникантов. Развитие международных контактов в сети Интернет, популярность экскурсий, образовательных программ по обмену в зарубежные страны предусматривает высокие требования к подготовке по иностранному языку не только взрослого населения, но и школьников. Данное положение требует нового подхода к обучению иностранным языкам, переосмысления целей обучения, которые, играя первостепенную роль, диктуют выбор форм, методов и содержания обучения.

Согласно требованиям ФГОС, предъявляемым к результатам обучения предметной области «Иностранный язык», они должны отражать сформированность иноязычной коммуникативной компетенции, необходимой для успешной социализации и самореализации, как инструмента межкультурного общения в современном поликультурном мире. [3] Но, по мнению многих ученых (Тер-Минасова С.Г., Гальскова Н.Д., Халеева И.И.), иноязычная коммуникативная компетенция не способна удовлетворить современным требованиям к подготовке студентов, готовых к межкультурному диалогу [1, 297]. Важность включения подготовки к активному межкультурному взаимодействию акцентируется и в Законе «Об образовании в Российской Федерации», вступившим в силу с 1 сентября 2013 г., в соответствии с которым содержание образования должно обеспечивать «интеграцию личности в национальную и мировую культуру» и «содействовать взаимопониманию и сотрудничеству между людьми, народами независимо от расовой, национальной, этнической, религиозной и социальной принадлежности, учитывать разнообразие мировоззренческих подходов».

С другой стороны, развитие современного общества подталкивает к осмыслению вопросов регионального уровня, национальной идентификации, потребностей своей собственной, национальной культуры и родного языка как части этой культуры, способного вести и направлять диалог культур. Эта способность в широком смысле и трактуется в современном понимании как межкультурная компетенция [8].

Приведенная традиция связи языков и культур не нова. Она получила развитие в середине $80-x$ годов прошлого века в рамках коммуникативной методической и дидактической теории обучения иностранным языкам. Именно тогда в социолингвистике и межкультурной коммуникации оформился новый подход, на- 
правленный на межнациональное взаимопонимание. Терминологически это отражается в таких понятиях, как кросскультурный, интеркультурный, межкультурный и межнациональный. В то же время это не вполне заметно на уровне регионального компонента, способного вести и направлять диалог культур. Таким образом, межкультурная компетенция охватывает все уровни подготовки будущих специалистов, но четко не отражена в программе по иностранному языку $[11,91]$.

Известно, что инновационные процессы в подготовке и образовании специалиста любого профиля происходят прежде всего на содержательном уровне, которые определяют структуру и конкретную наполняемость рабочих программ, методику работы с ними и учебнометодические и дидактические материалы, обеспечивающие учебный процесс $[3,13]$.

Межкультурная компетенция, в частности её региональный аспект формируется при учёте, как минимум, двух перспектив интер- и интракультурного уровня и реализует на их пересечении [8]. В современной реальности такой межкультурный компонент предполагает развитие способности вести диалог, формировать межкультурную толерантность к иным взглядам, обычаям, традициям к иному опыту, иным нормам и культурным представлениям, как внутри одной культуры, так и между культурами.

Межкультурная компетенция включает не только знание родного языка, но и иностранного. Все это создает не только основу для формирования национального самосознания, развития способности видеть собственную перспективу, свое место на рынке труда, развивает и совершенствует рыночную структуру, но и адаптирует к постоянным потребностям общества.

Формирование межкультурной компетенции должно занять центральное место в педагогическом процессе, что имеет особое значение именно сейчас, когда смешение народов, языков, культур достигло невиданного размаха, и остро встала проблема формирования межкультурной толерантности к иным культурам, пробуждения интереса и уважения к ним, преодоления в себе чувства раздражения от избыточности, недостаточности или просто непохожести других культур [11, 89].

Для формирования межкультурной компетенции в рамках действующих программ целесообразно пересмотреть традиционное распределение содержательных компонентов подготовки. Это, в свою очередь, позволит осуществить качественные модификации способов развития и формирования навыков выражения мыслей как на родном, так и на иностранном языке. На современном этапе отдельно методика преподавания иностранному языку и лингвистика не способны сфор- мировать единый языковой и речевой облик учащегося. Чтобы осуществить эти цели, необходимо не только освоить новые электронные технологии в обучении, но и привлечь новые учебные материалы нового поколения, отвечающие двум основным требованиям: учитывать межкультурную перспективу и составляющую учебного материала $[2,24]$.

Общая характеристика учебного материала межкультурной части определяется необходимостью обеспечить основу для развития способности воспринимать, видеть, слышать, чувствовать, сопоставлять, сравнивать явления и факты изучаемых на иностранных языках, давать определения, идентифицировать понятия, общаться, вести диалог.

Подобные требования непосредственно соотносятся с изменившейся иерархией мотивационных ценностей сегодняшних учащихся. Пересмотру существовавших принципов и жизненных ценностей, нашедших отражение как в структуре, так и в содержании учебных материалов и пособий по иностранным языкам во многом способствует сотрудничество с зарубежными коллегами и реальная поддержка зарубежных партнёров $[5,96]$.

Как показывает практика, создание материалов, направленных на формирование межкультурной компетенции, - процесс длительный и сложный. Ему предшествуют два важных периода:

1. накопления фактического материала для общетеоретической платформы в преломлении к конкретной ситуации;

2. анализ этой ситуации и актуальных потребностей.

Таким образом, невозможно ограничиться общими положениями и фактами, ориентированными на межкультурное общение [2, 22].

Развитие партнёрских контактов существенным образом влияет на профессиональные связи в различных областях, в том числе и в сфере иностранного языка. При активном участии коллег в России и за рубежом стало возможным создание общей концепции и самих учебнометодических комплексов с интеркультурной направленностью. Были разработаны учебные материалы для использования на средней ступени изучения иностранного языка, посвящённой наиболее традиционной, центральной форме функционирования языка - тексту, опредмечивающему и личностно ориентированному субстрату, воплощающему культуру, обычаи и традиции страны изучаемого языка $[4,15]$.

Исследование направлений межкультурной компетенции ещё далеки от своего завершения, поскольку самым непосредственным образом связано с вопросами социокультурной политики в нашей стране. 
В современном глобальном мире происходит увеличение культурных контактов, усиливается значение межкультурной коммуникации. Знакомство с чужой культурой начинается со сравнения или противопоставления своей собственной культуре, нормам, традициям и быту. В результате межкультурного общения формируются стереотипы, которые могут, как облегчать, так и затруднять восприятие чужой культуры. Стереотипные представления складываются из а) отношения к другим; б) отношения к самим себе. В данном случае культурная антитеза и этноцентризм являются механизмами восприятия чужого [10, 107].

В общественном сознании каждого социума имеется конгломерат идей и смыслов, представляющих собой ценностные ориентиры, позволяющие людям ориен- тироваться в многообразии жизни. Эти общественные представления фокусируются на значимых для социума характеристиках предмета или явления, о котором создается «общественное» суждение $[8,102]$.

Наряду с официальным восприятием, в массовом сознании существует множество стереотипов, составляющих своеобразную неофициальную часть социокультурного образа. В большинстве случаев неофициальный образ общества определенного народа складывается из стереотипов стихийно в соответствии с идеологическими определениями, которые возобладают в общественном сознании на низовом уровне. В общественном сознании, связанном с обыденным уровнем культуры, общественный имидж любой культуры формировался на основе нескольких механизмов.

\section{ЛИТЕРАТУРА}

1. Артемьева И.Н. Французский язык для обучения: новый подход к обучению// Вопросы методики преподавания в вузе. 2014. №3. С. 297-301.

2. Бабушкина Л.Е. Диагностика исходного уровня сформированности социокультурной компетенции при изучении иностранных языков// Гуманитарные науки и образование. 2013. №4 (16). С. 20-24.

3. Балыкина 0.В. Некоторые аспекты формирования социокультурной компетенции при обучении иностранным языкам в рамках внедрения ФГОС// С0временное общество, образование и наука сборник научных трудов по материалам международной научно-практической конференции 31 июля 2013 г.: в 5 частях. Тамбов, 2013. С. 14-15.

4. Белоцерковская Н.В. Формирование социокультурной компетенции при обучении иностранным языкам// Актуальные проблемы развития образования в России и за рубежом сборник материалов международной научной конференции. Главный редактор: Семенова Александра Дмитриевна, 2013. С. 1118.

5. Генсинская Э.А. Роль социокультурной компетенции в овладении иностранным языком// Вестник науки и образования. 2014. №2 (2). С. 96-104.

6. Дементьева А.П. Обучение побудительным речевым актам во французском языке// Наука и школа. 2014. №3. С. 137-143.

7. Елизарова Г.В. Культура и обучение иностранным языкам. СПб.: КАРО, 2005. 352 с.

8. Емельянова Е.В. Анализ соотношения уровня развития социокультурной компетенции и уровня обученности иностранным языкам// Вестник Российского университета дружбы народов. Серия: Вопросы образования. Языки и специальность. 2014. №4. С. 102-108.

9. Колесникова М.С. - [Электронный ресурс] Режим доступа: http:// mirznanii.com/info/regionalnyy-komponent-i-mezhkulturnaya- kompetentsiya-vpodgotovke-i-povyshenii-kvalifikatsii-uchitel_207443.

10. Корнилова О.С. Использование проблемно-коммуникативных задач в обучении французскому языку// Актуальные вопросы образования и науки сборник научных трудов по материалам международной научно-практической конференции: в 11 частях. 2014. С. 106-107.

11. Михеева Д.В. Использование современных средств обучения иностранным языкам в процессе формирования социокультурной компетенции у школьников// Проблемы современной лингводидактики. 2014. №11. С. 89-97.

12. Петухова Т.В. Социокультурный имидж как маркер общественных представлений// Журнал «Современные проблемы науки и образования». 2014 . №6.

13. Савельева Е.Б. Художественный фильм в обучении французскому языку// Проблемы и перспективы развития многоуровневой языковой подготовки в условиях поликультурного общества материалы II межрегиональной заочной научно-практической конференции. Казанский государственный университет культуры и искусств; составители: Каюмова Д.Ф., Новгородова Е.Е.; главный редактор: Д.Ф. Каюмова. 2015. С. 136-139.

14. Садохин А.П. Введение в теорию межкультурной коммуникации. - М.: Высшая школа, 2005. 254 с.

15. Струнина Н.В. Формирование социокультурной компетенции при обучении иностранным языкам// сборник статей XVI Международной научно-методической конференции. Посвящается 150-летию со дня рождения П.А. Столыпина. под ред. В.И. Волчихина, Р.М. Печерской. Пенза, 2012. С. $395-396$.

16. Фалькова Е.Г. Межкультурная коммуникация в основных понятиях и определениях: Методическое пособие. — СПб.: Ф-т филологии и искусств СПбГу, 2007. 77 c.

17. Фрик Т.Б. Основы теории межкультурный коммуникации: учебное пособие. Томск: Томский политехнический университет, 2013.100 с.

(с) Конколь Марина Михайловна (konkolio@mail.ru).

Журнал «Современная наука: актуальные проблемы теории и практики» 